\title{
Газохроматографическое определение формальдегида, метанола, фенола и крезолов в подгузниках методом парофазного анализа
}

\author{
Хабаров В.Б. ${ }^{1}$, Панина Л.И. ${ }^{2}$, Львов А.И. ${ }^{2}$ \\ ${ }^{l}$ ФГБУН Институт физической химии и электрохимии им. А.Н. Фрумкина РАН, Москва \\ ${ }^{2}$ НИОКО «Биоэкомониторинг», Москва
}

Поступила в редакцию 4.09.2018 г.

DOI: https://doi.org/10.17308/sorpchrom.2018.18/596

В статье приведены результаты газохроматографического анализа формальдегида, метанола, фенола и крезолов в подгузниках на основе целлюлозы методом парофазного анализа при температуpe $80^{\circ} \mathrm{C}$. Фенол и крезолы, экстрагируемые азотом из камеры с образцом подгузника концентрировали на полихроме-3 при комнатной температуре. Формальдегид и метанол переводили в дозирующую петлю объёмом $15 \mathrm{~cm}^{3}$ устройства для парофазного анализа и из петли вводили в аналитическую колонку. Для повышения чувствительности определения разделённые на колонке с полифенилхиноксалином формальдегид и метанол конвертировали в метан на никеле Ренея и детектировали ПИД газового хроматографа. Пробы фенолов, сконцентрированные на полихроме-3, вводили в аналитическую колонку с $2 \%$ полиэтиленгликольадипината на полихроме-1 методом термической десорбции.

Исследования показали, что в подгузниках содержится (мг/кг) формальдегида 10-30, метанола 5-10, фенола 1 и крезолов 0.4-2.0. Подгузник, содержащий 50\% целлюлозы и 50\% термомеханической массы, содержит больше формальдегида в 3 раза и метанола в 2 раза по сравнению с подгузником, содержащим $100 \%$ целлюлозной массы.

Подгузник, содержащий 50\% целлюлозы и 50 \% термомеханической массы, превышает ПДК по формальдегиду в 1.5 раза. Подгузники, содержащие 100 \% целлюлозы и $70 \%$ целлюлозы и $30 \%$ термомеханической массы, не превышают ПДК по формальдегиду.

Ключевые слова: газовая хроматография, парофазный анализ, подгузник, полифенилхиноксалин, полихром-3, полихром-1, полиэтиленгликольадипинат, формальдегид, метанол, фенол, крезолы.

\section{Gas chromatographic determination of formaldehyde, methanol, phenol and cresols in diapers by vapor phase analysis}

\author{
Khabarov V.B. ${ }^{1}$, Panina L.I. ${ }^{2}$, L'vov A.I. $^{2}$ \\ ${ }^{I}$ Federal State Budgetary Foundation of Science A.N. Frumkin Institute of Physical Chemistry and Electro- \\ chemistry of the Russian Academy of Sciences, Moscow \\ ${ }^{2}$ NIOKO «Bioecomonitoring», Moscow
}

The results of gas chromatographic analysis of formaldehyde, methanol, phenol and cresols in cellulose-based diapers by vapor phase analysis at a temperature of $80^{\circ} \mathrm{C}$ are presented in the article. The purpose of this study is to separate the gas chromatographic determination of formaldehyde, methanol, phenol and cresols in diapers $(\mathrm{mg} / \mathrm{kg}$ ) by vapor phase analysis and selective concentration of phenol and cresols on polychrome-3. Gas chromatographic determination of volatile organic compounds in diapers was performed by headspace at $80^{\circ} \mathrm{C}$. Phenol and cresols, nitrogen extracted from samples of diapers, 
concentrated on a polychrome-3 at room temperature. Formaldehyde and methanol were transferred into the dosing loop volume of $15 \mathrm{~cm}^{3}$ device headspace and injected from the dosing loop to an analytical column with polyphenylquinoxalines. To increase the detection sensitivity, separated on a column of polyphenylquinoxalines, formaldehyde and methanol are converted to methane on raney nickel at a temperature of $240{ }^{\circ} \mathrm{C}$ and detected by FID gas chromatograph. Samples phenols centered in the cartridge at the hub polychrome-3 was introduced into the analytical column with $2 \%$ to polietilenglikoladipinata polychrome- 1 by using a thermal desorption apparatus which eliminates smearing samples of phenols in the evaporator and the sorption on the silicone membrane vaporizer gas chromatograph.

Sanitary-chemical studies have shown that in diapers contained $(\mathrm{mg} / \mathrm{kg})$ formaldehyde $10-30,5-10$ methanol, phenol 1 and cresol 0.4-2.0. Diaper containing 50\% cellulose and 50\% thermomechanical pulp contains more formaldehyde in methanol and 3 times 2 times in comparison with the diapers containing $100 \%$ pulp.

A diaper containing $50 \%$ cellulose and $50 \%$ thermomechanical mass exceeds the MAC by formaldehyde 1.5 times. Diapers containing $100 \%$ cellulose and $70 \%$ cellulose and $30 \%$ thermomechanical mass do not exceed the maximum permissible concentration by formaldehyde. Developed a technique should be used for process control of sanitary-chemical characteristics of diapers and certification of safety indicators. For sanitary-chemical research diapers advisable to use headspace analysis with separate formaldehyde and methanol column polyphenylquinoxalines, concentration of phenols in the cartridge hub at polychrome- 3 and their introduction into the column with $2 \%$ polietilenglikoladipinata on polychrome-1 by thermal desorption.

Keywords: gas chromatography, headspace, polyphenylquinoxalines, nappy, polychrome-3, polychrome-1, polietilenglikoladipinat, formaldehyde, methanol, phenol, cresol.

\section{Введение}

Анализ нормативно-технических документов [1-6] показывает, что развитие производства и применение текстильных материалов бытового назначения и гигиенических материалов для разового пользования для детей и взрослых [7-12] выдвигают повышенные требования к качественной и количественной достоверности санитарно-химических характеристик (CXX) по формальдегиду, метанолу, фенолу и крезолам.

Принятый ГОСТ [2] содержит новые положения и процедуры, которые необходимо выполнять при разработке методик измерений количественных показателей продукции. Из справки Евразийской экономической комиссии (ЕЭК) [5] следует, что методики измерений являются объектами регулирования законодательства в области обеспечения единства измерений государств-членов. Методика измерений, не прошедшая метрологическую аттестацию, не может применяться в сферах государственного регулирования обеспечения единства измерений и перед использованием её разработчик методики должен получить свидетельство о метрологической аттестации.

По заключению межгосударственного совета по стандартизации, метрологии и сертификации ЕЭК аттестации подлежат свыше 600 ведомственных методик измерений, ранее включенных в Перечне стандартов к техническим регламентам Таможенного союза. Проблемой контроля производства и применения текстильных материалов бытового назначения [6-9] и гигиенических материалов разового пользования (подгузников) для детей и взрослых [6, 10-12] являются следующие:

- отсутствие точного современного метода газовой хроматографии (ГХ) для определения формальдегида, метанола, фенола, крезолов и других химических соединений;

- применение методических подходов по определению санитарно-химичеких характеристик (CXX) текстильных материалов бытового назначения, мкг/г, [6-9] и подгузниках для детей и взрослых только в водных экстрактах, мг/дм³, [6, 8] спектрофотометрическими методами; 
- применение ГОСТ [7] по определению формальдегида в тканях и изделиях спектрофотометрическим методом с ацетилацетоновым реактивом не обеспечивает получение достоверных количественных результатов; связано это с тем, что для градуировки спектрофотометра используются водные растворы формальдегида, которые представляют собой равновесную смесь моногидратаметиленгликоля $\mathrm{CH}_{2}(\mathrm{OH})_{2}$ и ряда гидратированных низкомолекулярных полимеров или полиоксиметиленгликолей с общей формулой $\mathrm{HO}\left(\mathrm{CH}_{2} \mathrm{O}\right)_{n} \mathrm{H}$; состояние равновесия зависит от температуры и концентрации формальдегида в растворе [13, с. 61];

- изменение состава водных растворов формальдегида при хранении [13]: а) реакция Канниццаро, состоящая в окислении одной молекулы формальдегида до муравьиной кислоты и восстановлении другой до метанола; б) образование метилаля: $\mathrm{CH}_{2} \mathrm{O}+2 \mathrm{CH}_{3} \mathrm{OH} \rightarrow \mathrm{CH}_{2}\left(\mathrm{OCH}_{3}\right)_{2}+\mathrm{H}_{2} \mathrm{O}$.

ГОСТ [9] регламентирует предельно допустимые концентрации, мкг/г, формальдегида для текстильных материалов бытового назначения в зависимости от слоя одежды и изделий в соответствии с их функциональным назначением и возрастом пользователей (табл. 1).

Таблица 1. Предельно допустимые концентрации формальдегида для текстильных материалах бытового назначения, мкг/Г*

\begin{tabular}{|c|c|c|c|c|}
\hline \multirow{2}{*}{ Слой одежды или изделий } & \multicolumn{5}{|c|}{ Содержание формальдегида в текстильных материалах, } \\
\cline { 2 - 5 } & $\begin{array}{c}\text { Для детей } \\
\text { до 1 года }\end{array}$ & $\begin{array}{c}\text { Для детей от 1 } \\
\text { года до 3 лет }\end{array}$ & $\begin{array}{c}\text { Для детей от 3 } \\
\text { лет до 18 лет }\end{array}$ & $\begin{array}{c}\text { Для взрос- } \\
\text { лых }\end{array}$ \\
\hline 1-й & 20 & 20 & 75 & 75 \\
\hline 2 -й & 20 & 75 & 75 & 300 \\
\hline 3-й & 20 & 300 & 300 & 300 \\
\hline $\begin{array}{c}\text { Одеяла, подушки, постельные } \\
\text { принадлежности, полотенца }\end{array}$ & 75 & 75 & 75 & 75 \\
\hline
\end{tabular}

*Формальдегид определяют спектрофотометрическим методом с ацетилацетоновым реактивом по ГОСТ [7].

К одежде и изделиям 1-го слоя относятся изделия, имеющие непосредственный контакт с кожей пользователя, такие, как нательное и постельное белье, головные уборы и др. Технический регламент [6] допускает в подгузниках из целлюлозы и ваты для детей содержание в водных экстрактах формальдегида 0.1 мг/дм ${ }^{3}$, метанола 0.2 мг/дм ${ }^{3}$ и не допускает содержание фенола и крезолов. Методические указания [6, 8] не регламентируют определение в подгузниках для детей содержание химических веществ в мкг/г или мг/кг. Методические указания [6] регламентируют определение химических соединений только в водной вытяжке из подгузников при насыщенности $1 \mathrm{~cm}^{2} / \mathrm{cm}^{3}$ в мг/дм ${ }^{3}$. В связи с этим результаты санитарно-химических исследований подгузников при насыщенности $1 \mathrm{~cm}^{2} / \mathrm{cm}^{3}$ дистиллированной воды в мг/дм ${ }^{3}$ невозможно сравнивать с результатами в мг/кг массы впитывающего слоя подгузника.

Методические указания [6] рекомендуют в водной вытяжке из подгузников определять формальдегид $\left(\right.$ мг/дм $\left.{ }^{3}\right)$ спектрофотометрическим методом с ацетилацетоновым реактивом и не приводят рекомендации по определению фенола и крезолов. В странах Евросоюза не разработаны стандарты по определению в подгузниках на основе целлюлозы химических веществ: формальдегида, метанола, фенола, крезолов методом ГХ.

В то же время в странах Евросоюза в сопроводительной документации на подгузники, изготовленные фирмами «Папиресет» и «Делипап» в Финляндии [14], 
приводится перечень определяемых химических веществ (мг/кг): формальдегид, метанол, фенол и крезолы методом ГХ.

В монографиях $[15,16]$ подробно рассмотрен газохроматографический анализ равновесной паровой фазы. В обзорах [17, 18] показано применение газохроматографического парофазного анализа (ПФА) - дискретной и непрерывной газовой экстракции твёрдых полимеров для определения летучих примесей и СXX полимерных материалов.

В [19-21] показано применение газохроматографического ПФА для определения формальдегида, метанола, метилаля и фенола в древесных композиционных материалах и синтетических смолах. Для ПФА использовали: разработанные устройства для ПФА [ 22] и для ввода проб органических веществ, сконцентрированных на сорбенте, в аналитическую колонку методом термической десорбции [21]; термостойкие полимерные сорбенты: полихром-3 - для избирательного концентрирования фенолов [23]; полифенилхиноксалин (ПФХ) - для разделения смеси: формальдегид, метанол, метилаль, вода $[19,24,25]$. В [26] применяли ПФХ для концентрирования и газохроматографического ПФА акрилонитрила и диметилформамида в полиакрилонитрильном волокне и тканях на его основе.

Цель настоящего исследования - раздельное газохроматографическое определение формальдегида, метанола, фенола и крезолов в подгузниках (мг/кг) методом парофазного анализа и избирательное концентрирование фенола и крезолов на полихроме-3.

\section{Эксперимент}

В работе использовали оборудование и расходные материалы: газовый хроматограф «Модель 3700, исп. 01» с ПИД, включённый в Госреестр; патронконцентратор (150x4 мм) из нержавеющей стали марки 12Х18Н10Т, заполненный полихромом-3, фр. 0.25-0.50 мм, с иглой из нержавеющей стали; термостат суховоздушный марки ТС-2Ц-450М (ТС80); электрические печи для десорбции органических веществ из патрона-концентратора, нагревания катализатора никеля Ренея и нагревания камеры из стекла с исследуемыми материалами, обеспечивающие температуру от 50 до $400^{\circ} \mathrm{C}$ с погрешностью $\pm 1.5^{\circ} \mathrm{C}$; регуляторы расхода газа-носителя из газового хроматографа для создания потока азота через диффузионные ячейки с метанолом, фенолом, м-крезолом и в камере с исследуемыми образцами подгузников; реактор для конверсии метанола в формальдегид - трубка из кварцевого стекла, внутрь которой впаяна спираль из нихрома марки X20Н80 [27, 28]; индивидуальные вещества: фенол, о-, м-, п-крезолы х. ч., метанол для хроматографии.

Устройство для анализа органических веществ в подгузниках методом ПФА (рис. 1). Разработанное устройство для ПФА с петлей объёмом $15 \mathrm{~cm}^{3}$ [22] монтировали в термостате колонок газового хроматографа. Для нагревания камеры с исследуемым образцом подгузника использовали электрическую печь. Для избирательного концентрирования фенолов из парогазового потока использовали патронконцентратор с полихромом-3. Введение в аналитическую колонку парогазовой пробы из подгузника, содержащей формальдегид и метанол, осуществляли с дополнительным расходом газа-носителя через дроссели.

Устройство для введения проб органических веществ, сконцентрированных на сорбенте, в аналитическую колонку методом термической десорбции. Разработанное устройство [21] монтировали на газовом хроматографе. Устройство содержит два регулятора расхода в канале газа-носителя газового хроматографа и кран- 
переключатель потока. При вводе пробы органических веществ, сконцентрированных на сорбенте, из патрона-концентратора в аналитическую колонку - от первого регулятора расхода газ-носитель проходит через патрон-концентратор и вымывает пробу в испарительную камеру; от второго регулятора расхода газ-носитель поступает в испаритель газового хроматографа и продувает объём между иглой патронаконцентратора и мембраной испарителя, и исключает размывание анализируемой пробы органических веществ в испарителе и их сорбцию на силиконовой мембране испарителя газового хроматографа.

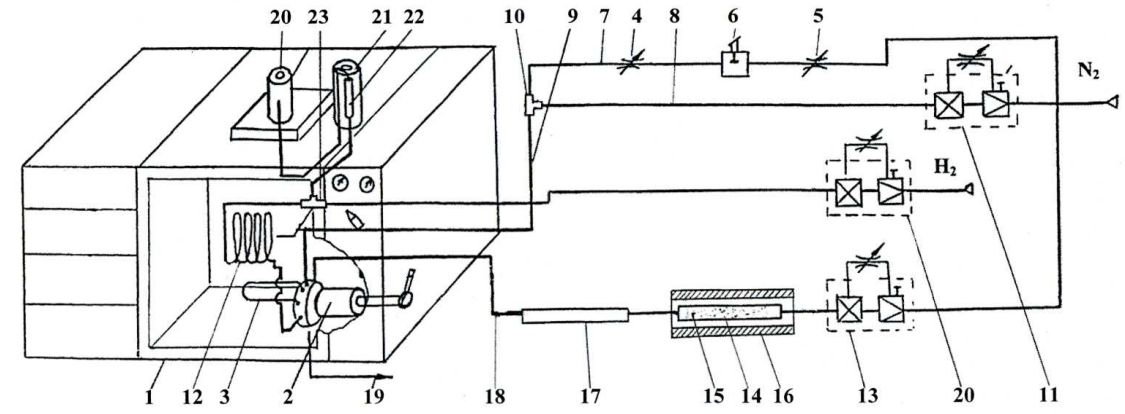

Рис. 1. Анализ летучих органических веществ в подгузниках с помощью устройства для ПФА и избирательное концентрирование фенолов на полихроме-3.

1 - газовый хроматограф; 2 - кран-дозатор; 3 - дозирующая петля объёмом $15 \mathrm{~cm}^{3}$; 4, 5 - дроссели; 6 - мембранный кран; 7, 8, 10, 18, 19 - линии газа-носителя; 9, 23 - тройники; 11, 13, 20 - регуляторы расхода газа-носителя и водорода; 12 - аналитическая колонка из стекла (2 мх4 мм) с ПФХ; 14 - камера из стекла $\left(1.5 \mathrm{~cm}^{3}\right) ; 15$ - исследуемый образец подгузника; 16 - электрическая печь; 17 - патрон-концентратор с полихромом-3; 20 - ПИД; 21 - электрическая печь; 22 - ячейка с никелем Ренея на кизельгуре.

Газохроматографическое определение органических веществ в подгузниках методом ПФА (рис. 1). Навеску подгузника 0.4 г помещали в камеру из стекла объёмом $1.5 \mathrm{~cm}^{3}$, которую нагревали в электрической печи. Вход камеры с образцом соединяли с регулятором расхода азота, а выход - с патроном-концентратором, заполненным полихромом-3, фр. 0.25-0.50 мм, и устройством для ПФА с дозирующей петлей объёмом $15 \mathrm{~cm}^{3}$. Экстрагирование органических веществ из образца подгузника проводили в следующем режиме: 17 минут нагревали камеру с образцом при $80^{\circ} \mathrm{C}$, затем через неё прокачивали азот с объёмной скоростью $5 \mathrm{~cm}^{3} /$ мин объёмом $10 \mathrm{~cm}^{3}$. Фенол и крезолы, экстрагируемые азотом из камеры с подгузником, концентрировали на полихроме-3 при комнатной температуре, а формальдегид и метанол переводили в петлю крана-дозатора, а из петли вводили в аналитическую колонку.

По 9 анализам летучих веществ, выделяющихся из подгузника, строили график зависимости логарифма концентрации $(\lg C)$ формальдегида, метанола, фенола и крезолов, выделяющихся из подгузника при температуре $80^{\circ} \mathrm{C}$, от времени газовой экстракции ( $t$ ) (рис. 2) и по графику проводили количественный расчёт (табл. 3).

Условия газохроматографического анализа формальдегида и метанола в подгузниках.

Для повышения чувствительности определения формальдегида на ПИД газового хроматографа использовали метод реакционной ГХ. Разделённые на аналитической колонке формальдегид и метанол конвертировали в метан на катализаторе никеле Ренея на кизельгуре, фр. 0.25-0.30 мм, при температуре $240^{\circ} \mathrm{C}$ и детектировали ПИД газового хроматографа.

Условия анализа: устройство для ПФА с петлей объёмом 15 см$^{3}$ [22]; колонка из стекла (2 мх4 мм) с ПФХ, фр. 0.15-0.20 мм; пробу из дозирующей петли в анали- 
тическую колонку вводили при объёмной скорости газа-носителя азота $280 \mathrm{~cm}^{3} / \mathrm{мин;}$ объёмная скорость азота через колонку $30 \mathrm{~cm}^{3} /$ мин, водорода через ячейку с никелем Ренея $30 \mathrm{~cm}^{3} /$ мин, воздуха $300 \mathrm{~cm}^{3} / \mathrm{мин;} \mathrm{температура:} \mathrm{колонки} 130^{\circ} \mathrm{C}$, ячейки с никелем Ренея на кизельгуре $240^{\circ} \mathrm{C}$, ПИД $150{ }^{\circ} \mathrm{C}$; скорость диаграммной ленты $1 \mathrm{~cm} / \mathrm{мин;}$ шкала измерения $10 \times 10^{-10} \mathrm{~A}-100 \times 10^{-10} \mathrm{~A}$.

Условия газохроматографического анализа фенолов в подгузниках. Условия анализа: сконцентрированные на полихроме-3 фенол и крезолы, выделяющиеся из подгузника, вводили из патрона-концентратора в аналитическую колонку методом термической десорбции с помощью устройства [21]; колонка из стекла (2 мх3 мм) с $2 \%$ ПЭГА на полихроме-1, фр. 0.25-0.50 мм; объёмная скорость газа-носителя азота через патрон-концентратор $27 \mathrm{~cm}^{3} /$ мин, через канал испарителя $3 \mathrm{~cm}^{3} /$ мин, что обеспечивает поддув между иглой патрона-концентра-тора и мембраной испарителя. Объёмная скорость водорода $30 \mathrm{~cm}^{3} /$ мин, воздуха $300 \mathrm{~cm}^{3} /$ мин. Температура колонки $160^{\circ} \mathrm{C}$, испарителя $160^{\circ} \mathrm{C}$, ПИД $180^{\circ} \mathrm{C}$, десорбции $160^{\circ} \mathrm{C}$, время десорбции 10 мин; скорость диаграммной ленты $1.5 \mathrm{~cm} /$ мин, шкала измерения $2 \times 10^{-11} / 16 \mathrm{~A}$.

Динамический способ создания градуировочных смесей фенола и м-крезола в азоте и градуировка ПИД газового хроматографа [21]. Для создания динамическим методом градуировочных смесей паров фенола и м-крезола в азоте использовали ампулы из фторопласта Ф-4МБ [ 29]. В ампулы вводили по 5 г фенола и м-крезола, запаивали и помещали в стеклянную ячейку при температуре $60^{\circ} \mathrm{C}$ и через неё от регулятора расхода подавали азот с объёмной скоростью $10 \mathrm{~cm}^{3} /$ мин. К обогреваемому выходу ячейки с фенолом и м-крезолом присоединяли патрон-концентратор, заполненный полихромом-3, фр.0.25-0.50 мм, и прокачивали парогазовые пробы объёмом 50-200 $\mathrm{cm}^{3}$. Калибровку ампул с фенолом и м-крезолом осуществляли по потере их массы в течение 30 суток. Условия анализа градуировочных смесей фенола и мкрезола в азоте см. в разделе «Условия газохроматографического анализа фенолов в подгузниках».

Динамический способ создания градуировочных смесей метанола и формальдегида в азоте $[27,28]$ и градуировка ПИД газового хроматографа с помощью устройства для ПФА [22].

Создание динамическим методом градуировочных смесей метанола и формальдегида в потоке азота проводили в соответствии с [27, 28]. На первом этапе создавали градуировочную смесь абсолютного метанола с помощью ампулы из фторопласта Ф-4МБ [29] в потоке азота. Ампулу с метанолом помещали в стеклянную ячейку при температуре $67^{\circ} \mathrm{C}$ и через неё подавали от регулятора расхода поток газаносителя азота с объёмной скоростью $5-20 \mathrm{~cm}^{3} /$ мин. Калибровку ампулы с метанолом осуществляли по потере массы в течение 30 суток. На втором этапе поток азота, содержащий метанол, направляли в реактор с катализатором, содержащим $20 \%$ хрома и $80 \%$ никеля; при температуре $500^{\circ} \mathrm{C}$ происходит количественная конверсия метанола в формальдегид. Условия анализа градуировочных смесей формальдегида и метанола в азоте см. в разделе «Условия газохроматографического анализа формальдегида и метанола в подгузниках».

\section{Обсуждение результатов}

Для разделения смеси, содержащей формальдегид, метанол, воду, использовали полимерный сорбент ПФХ, который обладает макропористой структурой (диаметр пор $1600 \AA$ А), развитой удельной поверхностью $\left(68.1 \mathrm{~m}^{2} / \Gamma\right)$ и температурным пределом использования $320^{\circ} \mathrm{C}$ [24]. На ПФХ разделяется смесь: формальдегид, ме- 
танол, вода, причём последовательность элюирования компонентов аналогична наблюдаемой на порапаке $\mathrm{N}$ [25].

На колонке (2 мх3-4 мм) с ПФХ, наблюдается полное разделение смеси: формальдегид, метанол, вода, метилаль в указанной последовательности $[19,25]$.

При создании градуировочных смесей метанола в азоте с помощью фторопластовой ампулы динамическое равновесие выделения метанола при температуре $67 \pm 0.1^{\circ} \mathrm{C}$ остается постоянным в течение всего времени работы диффузионной ячейки - 2 лет. Конверсия метанола в формальдегид в реакторе с катализатором, содержащим $20 \%$ хрома и $80 \%$ никеля, при температуре $500^{\circ} \mathrm{C}$ достигает $98 \pm 2 \%$ без образования побочных органических соединений и позволяет проводить с высокой точностью градуировку ПИД газового хроматографа. При использовании устройства для ПФА с дозирующей петлей объёмом $15 \mathrm{~cm}^{3}$ относительная погрешность измерений градуировочных смесей формальдегида $\pm 1.5 \%$ и метанола $\pm 2.0 \%(P=0.95, n=7)$ [19].

Применение в [20] динамического метода создания градуировочных смесей метанола и формальдегида в азоте $[27,28]$ позволило получить методом ГХ достоверные санитарно-химические характеристики древесных композиционных материалов и синтетических смол.

При создании градуировочных смесей паров фенола и м-крезола в азоте с помощью фторопластовых ампул динамическое равновесие выделения фенола и мкрезола при температуре $60 \pm 0.1^{\circ} \mathrm{C}$ устанавливается в течение 5 суток. Скорость диффузии фенола и м-крезола через стенки ампул остается постоянной и это подтверждает градуировка ампул по потере массы в течение 30 суток (табл. 2).

Таблица 2. Характеристики динамического метода создания градуировочных смесей паров фенола и м-крезола в азоте с помощью фторопластовых ампул Ф-4МБ $(13 \times 1.5 \mathrm{~cm})$

\begin{tabular}{|c|c|c|c|c|c|}
\hline $\begin{array}{c}\text { Опреде- } \\
\text { ляемое } \\
\text { вещество }\end{array}$ & $\begin{array}{c}\text { Темпе- } \\
\text { ратура } \\
\text { ячейки, }{ }^{\circ} \mathrm{C}\end{array}$ & $\begin{array}{c}\text { Скорость азота } \\
\text { через ячейку, } \\
\text { см }^{3} / \text { ч }\end{array}$ & $\begin{array}{c}\text { Потеря массы } \\
\text { ампулы за 1 ч, } \\
\text { мг } \cdot 10^{-5}\end{array}$ & $\begin{array}{c}\text { Концентрация } \\
\text { вещества в азо- } \\
\text { те, мг/дм }{ }^{3} \times 10^{-5}\end{array}$ & $\begin{array}{c}\text { *Сконцентрировано } \\
\text { на полихроме-3, } \\
\text { мг } \cdot 10^{-5}\end{array}$ \\
\hline Фенол & 60 & $600 \pm 2 \%$ & 570.27 & 950.44 & 47.52 \\
М-крезол & 60 & $600 \pm 2 \%$ & 5173.10 & 8621.90 & 431.09 \\
\hline
\end{tabular}

*Количество рассчитывали по формуле: $C=[M \cdot V]: U$, где $C$ - количество фенола и м-крезола, сконцентрированных на полихроме-3 в патроне-концентраторе, мг; $M$ - потеря массы фторопластовой ампулы с фенолом или м-крезолом, мг/ч; $U$ - скорость азота через стеклянную ячейку, $\mathrm{cm}^{3} /$ ч $V-$ объём прокаченной пробы через патрон-концентратор с полихромом-3 градуировочной смеси паров фенола и м-крезола в азоте, приведённый к нормальным условиям по формуле: $V=\left[P_{1} \cdot T_{2} \cdot V_{1}\right]:\left[T_{1}+t\right] P_{2}$.

Для избирательного концентрирования фенолов из парогазовых проб использовали сорбент - полихром-3 [21, 23]. В [21] для оценки сорбционной ёмкости патрона-концентратора с полихромом-3 при температуре $20^{\circ} \mathrm{C}$ определяли удельные объёмы удерживания фенолов (табл. 3) и, соответственно, объёмы до «проскока», объёмы «до равновесия» и коэффициенты обогащения при концентрировании фенола и крезолов.

При количественном определении фенолов для патрона-концентратора с полихромом-3 рассчитывали объёмы «до проскока» и «до равновесия» в соответствии c [30]. Коэффициент обогащения при концентрировании микропримесей на сорбентах определяется отношением объёмов удерживания анализируемых веществ при температурах адсорбции и десорбции и является определяющим при выборе сорбен- 
та для концентрирования [31].

Легкокипящие вещества - формальдегид, метанол, метилаль, вода при комнатной температуре не удерживаются полихромом-3, в то же время фенол и крезолы характеризуются достаточно большими величинами $\mathrm{V}_{\mathrm{g}}$, что позволяет осуществлять их избирательное концентрирование из парогазовых сред и проводить термическую десорбцию при температуре $160^{\circ} \mathrm{C}$, так как теплоты адсорбции $\left(\mathrm{Q}_{\mathrm{a}}\right)$ на полихроме-3 относительно низкие (табл. 3).

Таблица 3. Удельные объёмы удерживания $\left(\mathrm{V}_{\mathrm{g}}, \mathrm{cm}^{3} / \Gamma\right)$, объёмы удерживания «до проскока» $\left(\mathrm{V}_{\mathrm{r}}, \mathrm{cm}^{3}\right)$, теплоты адсорбции $\left(\mathrm{Q}_{\mathrm{a}}\right.$, кДж/моль) сорбатов на полихроме-3 при температуре $20^{\circ} \mathrm{C}$ и коэффициенты обогащения

\begin{tabular}{|c|l|c|c|c|c|c|}
\hline № & Сорбаты & $\begin{array}{c}\text { T кипе- } \\
\text { ния, }{ }^{\circ} \mathrm{C}\end{array}$ & $\mathrm{V}_{\mathrm{g}}, \mathrm{cm}^{3} / \Gamma$ & $\begin{array}{c}* \mathrm{Q}_{\mathrm{a}}, \\
\text { кДж/моль }\end{array}$ & $\begin{array}{c}\mathrm{V}_{\mathrm{r}} \text { «до проскока» } \\
\text { (вес 1.7 г), } \text { см}^{3}\end{array}$ & $\begin{array}{l}\text { Коэффициенты } \\
\text { обогащения }\end{array}$ \\
\hline 1 & Фенол & 182.4 & 92 & 35.1 & 107 & 48 \\
\hline 2 & О-крезол & 190.8 & 203 & 39.2 & 214 & 182 \\
\hline 3 & П-крезол & 202.0 & 364 & 44.0 & 441 & 343 \\
\hline 4 & М-крезол & 202.8 & 372 & 44.0 & 412 & 365 \\
\hline
\end{tabular}

*Теплоту адсорбции рассчитывали по формуле:

$$
\mathrm{Q}_{\mathrm{a}}=\frac{2}{3} \cdot \mathrm{R} \cdot \frac{\Delta \mathrm{lgV}_{\mathrm{g}}}{\Delta(1 / \mathrm{T}) \cdot 10^{-3}}(\text { КДж/моль }),
$$

где R - универсальная газовая постоянная, равная 8.314.10-3 кДж/моль К; $\Delta \lg _{\mathrm{g}}$ - разность логарифмов удельных удерживаемых объёмов сорбата, измеренных при двух значениях температур хроматографической колонки (патрона-концентратора); $\Delta(1 / \mathrm{T})$ - разность обратных температур $\mathrm{T}_{1}$ и $\mathrm{T}_{2},{ }^{\circ} \mathrm{K}$.

Так, в патроне-концентраторе с полихромом-3 при температуре $20^{\circ} \mathrm{C}$ объёмы

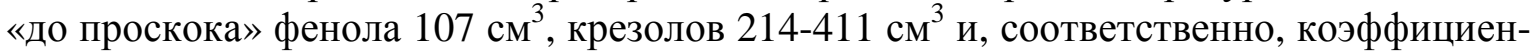
ты обогащения 48 и 182-343, что позволяет избирательно концентрировать фенол и крезолы, выделяющиеся из подгузников, при газовой экстракции азотом.

Избирательное концентрирование фенола и крезолов, выделяющихся из подгузников, в патроне-концентраторе на полихроме-3 при комнатной температуре исключает их химическое взаимодействие с формальдегидом. Введение сконцентрированных на полихроме-3 проб фенола и крезолов из патрона-концентратора в аналитическую колонку из стекла с $2 \%$ ПЭГА на полихроме- 1 методом термической десорбции с помощью устройства [21], исключает размывание пробы фенолов в испарителе и их сорбцию на силиконовой мембране испарителя газового хроматографа и обеспечивает полное разделение фенола и крезолов.

Применение устройства [21] и полихрома-3 [23] для концентрирования градуировочных смесей фенола и м-крезола из азота, позволяет оптимизировать температуру десорбции $160^{\circ} \mathrm{C}$ при вводе проб из патрона-концентратора в аналитическую колонку. Относительная погрешность измерений градуировочных смесей фенола $\pm 1.4 \%$, м-крезола $\pm 1.2 \%$ ( $\mathrm{P}=0.95, \mathrm{n}=7)$.

В [19-21] приведена методология расчёта содержания формальдегида, метанола и фенола в фанере и шпоне. Для расчёта использовали график зависимости $l g$ концентрации $(C)$ от времени газовой экстракции $(t)$ при температуре $80-84^{\circ} \mathrm{C}$. Ниспадающие участки зависимости $\lg C$ формальдегида, метанола и фенола от $t$ имеют прямолинейную зависимость. Такая закономерность характерна для веществ, выделяющихся из композиционных материалов за счёт диффузии. Эта закономерность выделения формальдегида, метанола, фенола и крезолов аналогична и для подгузни- 
ков (рис. 2). Для веществ, выделяющихся за счёт испарения, $\lg C$ от $t$, зависимость непрямолинейная.

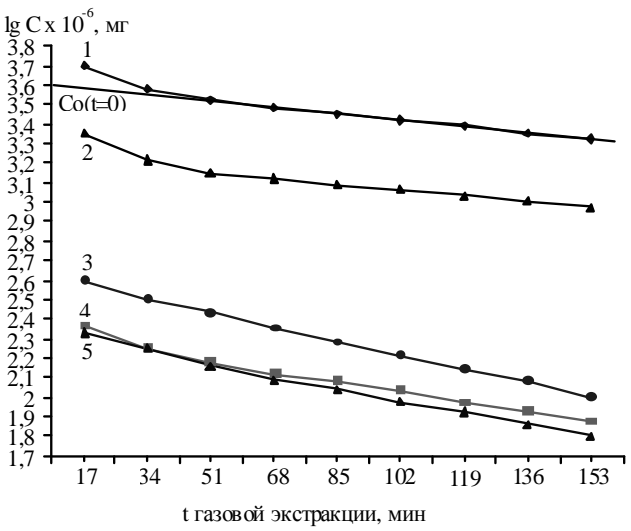

Рис. 2. Зависимость логарифма концентрации формальдегида, метанола, фенола, м- и о-крезолов, выделяющихся из подгузника при температуре $80^{\circ} \mathrm{C}$,

от времени газовой экстракции: 1 - формальдегид, 2 - метанол, 3 - фенол, 4 - м-крезол, 5 - о-крезол, экстрагируемые азотом из подгузника (вес 0.4 г) в камере из стекла (объём $1.5 \mathrm{~cm}^{3}$ ).

При газохроматографическом определении методом ПФА химических веществ в подгузниках предел детектирования формальдегида 0.0015 мг/кг, метанола 0.0016 мг/кг, фенола 0.006 мг/кг, м-крезола 0.009 мг/кг.

Санитарно-химические исследования показали (табл. 4), что подгузник, содержащий 50\% целлюлозы и 50\% термомеханической массы, содержит формальдегида больше в 3 раза и метанола в 2 раза по сравнению с подгузником, содержащим $100 \%$ целлюлозной массы.

Таблица 4. Результаты газохроматографического определения формальдегида, метанола, фенола и крезолов в подгузниках на основе целлюлозы (внутренний слой), изготовленных в Финляндии фирмами «Делипап» и «Папиресет», методом парофазного анализа, мг/кг

\begin{tabular}{|c|c|c|c|c|c|c|c|}
\hline \multirow{2}{*}{ № } & *Рецептура детских подгузни- & \multicolumn{5}{|c|}{ Концентрация, мг/кг } \\
\cline { 5 - 8 } & $\begin{array}{c}\text { кормаль- } \\
\text { дегид }\end{array}$ & метанол & фенол & о-крезол & п-крезол & м-крезол \\
\hline 1 & $\begin{array}{c}\text { Содержит 50 \% целлюлозной } \\
\text { массы и 50 \% химической тер- } \\
\text { момеханической массы }\end{array}$ & 30.0 & 10.0 & 1.0 & $\begin{array}{c}\text { менее } \\
0.009\end{array}$ & $\begin{array}{c}\text { менее } \\
0.009\end{array}$ & 1.0 \\
\hline 2 & $\begin{array}{c}\text { Содержит 70 \% целлюлозной } \\
\text { массы и 30 \% химической тер- } \\
\text { момеханической массы }\end{array}$ & 20.0 & 5.0 & 1.0 & 0.5 & 0.4 & 0.5 \\
\hline 3 & $\begin{array}{c}\text { Содержит 100\% целлюлозной } \\
\text { массы }\end{array}$ & 10.0 & 5.0 & 1.0 & 0.5 & $\begin{array}{c}\text { менее } \\
0.009\end{array}$ & 0.5 \\
\hline
\end{tabular}

Для определения содержания о-крезола в подгузниках использовали градуировочный коэффициент м-крезола. Концентрацию веществ, выделяющихся из подгузника за счёт испарения, рассчитывали по формулам: $C_{1}=[S \cdot K \cdot 100]: M$; $C_{2}=[S \cdot K \cdot 0,94 \cdot 100]: M$, где $C_{1}$ - концентрация метанола, фенола, крезола в образце, мг/кг массы; $C_{2}-$ концентрация формальдегида в образце, мг/кг массы; $S$ - площадь хроматографических пиков, мм²; К- градуировочные коэффициенты метанола, формальдегида, фенола, м-крезола, мг/мм²; 0.94- коэффициент пересчёта в формальдегид; М - вес образца, г. Концентрацию веществ, выделяющихся из подгузника за счёт диффузии, рассчитывали по формуле: $C=\left[C_{0} \cdot 100\right]: M$, где $\mathrm{C}-$ концентрация формальдегида и метанола в образце, мг/кг массы; $C_{0}$ - концентрация формальдегида и метанола в образце, мг $10^{-6}$, получаемая линейной экстраполяцией ниспадающегося участка $\lg C_{0}$ от $t$ газовой экстракции на ось абсцисс ( $\left.t=0\right)$ на рис. $2 ; M-$ вес образца, г. 
Сравнение результатов санитарно-химических исследований показали, что подгузник, содержащий 50 \% целлюлозы и 50 \% термомеханической массы, превышает ПДК по формальдегиду (табл. 1) в 1.5 раза. Подгузники, содержащие $100 \%$ целлюлозы и $70 \%$ целлюлозы и $30 \%$ термомеханической массы, не превышают ПДК по формальдегиду. При газохроматографическом определении содержания формальдегида и метанола в подгузниках с помощью устройства для ПФА с дозирующей петлей объёмом $15 \mathrm{~cm}^{3}$ [22], относительная погрешность измерений формальдегида $\pm 4.5 \%$ и метанола $\pm 5 \%(P=0.95, n=5)$.

При газохроматографическом определении содержания фенола и крезолов в подгузниках методом ПФА и избирательном концентрировании их на полихроме-3 с последующим введением пробы из патрона-концентратора в аналитическую колонку методом термической десорбции с помощью устройства [21], относительная погрешность измерений фенола $\pm 6 \%$ и м-крезола \pm 5-7 \% $(P=0.95, n=5)$.

\section{Заключение}

Для определения химических веществ, содержащихся в подгузниках на основе целлюлозы (мг/кг), целесообразно использовать метод газовой хроматографии. Применение устройства для ПФА с дозирующей петлей объёмом 15 $\mathrm{cm}^{3}$ [22], аналитической колонки с полифенилхиноксалином для определения формальдегида и метанола в виде метана, избирательное концентрирование фенола и крезолов на полихроме-3 и их введение в аналитическую колонку с 2 \% ПЭГА на полихроме-1 методом термической десорбции с помощью устройства [21] обеспечивает получение достоверных санитарно-химических характеристик подгузников по формальдегиду, метанолу, фенолу и крезолам, мг/кг.

Санитарно-химические исследования показали, что в подгузниках содержится (мг/кг) формальдегида 10-30, метанола 5-10, фенола 1 и крезолов 0.4-2.0. Подгузник, содержащий 50\% целлюлозы и 50\% термомеханической массы, содержит формальдегида больше в 3 раза и метанола в 2 раза по сравнению с подгузником, содержащим $100 \%$ целлюлозной массы.

Сравнение результатов санитарно-химических исследований показали (мг/кг), что подгузник, содержащий 50\% целлюлозы и 50\% термомеханической массы, превышает ПДК по формальдегиду в 1.5 раза. Подгузники, содержащие $100 \%$ целлюлозы и 70\% целлюлозы и 30\% термомеханической массы, не превышают ПДК по формальдегиду.

Разработанную методику целесообразно использовать для технологического контроля санитарно-химических характеристик подгузников и сертификации по показателям безопасности.

Для санитарно-химических исследований подгузников целесообразно использовать газохроматографический парофазный анализ с раздельным анализом формальдегида и метанола на колонке с полифенилхиноксалином, концентрирование фенолов в патроне-концентраторе на полихроме-3 и их введение в колонку с $2 \%$ ПЭГА на полихроме-1 методом термической десорбции.

\section{Список литературы}

1. РМГ 29-2013. Государственная система обеспечения единства измерений. Метрология. Основные термины и определения.
2. ГОСТ 8.010-2013. Межгосударственный стандарт. Государственная система обеспечения единства измерений. Методики выполнения измерений. Основные положения. 
3. ПГМ 126-2013. Правила по межгосударственной стандартизации. ГСИ. Порядок аттестации методик выполнения измерений и их применение в сферах законодательной метрологии государств - участников Содружества Независимых Государств. Введены в действие в качестве рекомендаций по метрологии Российской Федерации с 01.03.2015 г.

4. «Об утверждении Порядка аттестации методики (метода) измерений, принимаемой в качестве референтной методики (метода) измерений». Утверждён ЕЭК 07.06.2016 N 68.

5. Информационно-аналитическая справка о последствиях влияния проекта решения ЕЭК на условия ведения предпринимательской деятельности на проект решения: «Об утверждении Порядка метрологической аттестации методики (метода) измерений».

6. Технический регламент таможенного союза ТР ТС 007/2011 «О безопасности продукции, предназначенной для детей и подростков». Утверждён 23.09.2011 г. № 797.

7. ГОСТ 256170-2014 Межгосударственный стандарт. Ткани и изделия льняные, полульняные, хлопчатобумажные и смешанные. Методы химических испытаний. М.: ФГУП «Стандартинформ». 2015. 67 с. Введ. 01.01.2016.

8. Методические указания МУК 4.1/4.3.1485-03. Гигиеническая одежда для детей, подростков и взрослых. Утв. гл. сан. врачом РФ Онищенко Г.Г. 20.06.2003.

9. ГОСТ Р 50729-95. Материалы текстильные. Предельно допустимые концентрации свободного формальдегида. М.: Из-во стандартов. 1995. 3 с. - Введ. 01.01.1996. Изменения $\mathrm{N} 1$ от 25.12.2014 и введ. 01.07.2015) (принят в качестве межгосударственного стандарта ГОСТ 30386-95).

10. ГОСТ Р 52557-2011. Подгузники детские бумажные. Общие технические условия. М.: ФГУП «Стандартинформ». 2012. 18 с. - Введ. 2012.03.01.

11. ГОСТ Р 55082-2012. Изделия бумажные медицинского назначения. Подгузники для взрослых. Общие технические условия. М.: ФГУП «Стандартинформ». 2014. 24 с. Введ. 01.01.2014.

12. ГОСТ Р 5080-2018 Материал композиционный на основе целлюлозы для впитывающих бумажных изделий санитарногигиенического назначения. Технические условия. М.: ФГУП «Стандартинформ». 2018. 7 с. - Введ. 2018.08.01.

13. Уокер Дж. Ф. Формальдегид. Пер. с англ. Госхимиздат, 1957. 608 с.

14. Товаросопроводительные документы и сертификаты соответствия на гигиенические изделия для детей - подгузники на основе целлюлозы, изготовленные в Финляндии фирмами «Папиресет» и «Делипап».

15. Хахенберг Х., Шмид А. Газохроматографический анализ равновесной паровой фазы: Пер. с англ. М.: Мир, 1979. 160 с.

16. Виттенберг А.Г., Иоффе Б.В. Газовая экстракция в хроматографическом анализе. Парофазный анализ и родственные методы. Л.: Химия, 1982. 279 с.

17. Иоффе Б.В., Резник Т.Л. // Журн. аналит. химии. 1980. Т. 35. № 7. С. 1410-1427.

18. Бурейко А.С., Иоффе Б.В. // Журн. аналит. химии. 1991. Т. 46. № 3. С. 452-460.

19. Хабаров В.Б. // Аналитика и контроль. 2013. T.17. № 2. C. 196-203.

20. Хабаров В.Б. // Сорбичионные и хроматографические прочессы. 2015. Т. 15. № 2. C. 196-215.

21.Хабаров В.Б. // Сорбционные и хроматографические прочессы. 2013. Т. 13. № 6. C. 947-958.

22. Хабаров В.Б., Мальцев В.В. А.С. СССР № $1728793,1992$.

23. Хабаров В.Б., Панина Л.И., Сакодынский К.И., Ковба И.Т., Глазунова Л.Д. А.С. № 1258179 СССР, 1986.

24. Глазунова Л.Д., Панина Л.И., Сакодынский К.И., Забельников Н.С. А.С. СССР № 699422, 1979.

25. Глазунова Л.Д., Панина Л.И., Сакодынский К.И. // Тезисы докладов «Применение хроматографии в химии и химической промышленности». 10-12 июня 1981 г. Пермь 1981, c. 4.

26. Хабаров В.Б., Панина Л.И., Чумичева О.А. // Сорбиионные и хроматографические проиессы. 2014. Т. 14. № 2. С. 240-253.

27. Хабаров В.Б., Мальцев В.В. А.С. СССР № $1350610,1987$.

28. Хабаров В.Б. // Сорбционные и хроматографические прочессы. 2012. Т. 12. № 4. C. 513-522.

29. Технические условия 301-05-89-90. Ампулы фторопластовые. Кирово-Чепецкий химический комбинат. $1990.9 \mathrm{c}$.

30. Raymond A., Guiochon G. // J. Chromatog. Sci. 1975. Vol. 13. pp. 173-177. 
31. Гаврилина Л.Я., Жейвот В.И., Емельянов И.Д. // Изв.СО АН СССР. 1982. № 7. С.

\section{References}

1. RIS 29-2013. State system for ensuring the uniformity of measurements. Metrology. Basic terms and definitions.

2. GOST 8.010-2013. State system for ensuring the uniformity of measurements. Procedures of measurements. Main principles.

3. RIS 126-2013. State system for ensuring the uniformity of measurements.Rules for certification of measurement applied in the field of legal metrolodgy of the states-members of CIS.

4. "On the Approval of the Procedure for the Certification of the Measurement Technique (Method), Accepted as a Reference Measurement Technique (Method)". Approved by the Eurasian Economic Commission 07.06.2016 N. 68.

5. Analytical information on the impact of the draft ECE decision on business conditions for the draft decision: "On approval of the Order of metrological certification of the measurement technique (measurement method)".

6. Technical regulations of the customs union of TR TS 007/2011 "On the safety of products intended for children and adolescents". Approved 23.09.2011 г. N 797.

7. GOST 256170-2014. Linen, semilinen, cotton and mixed fabrics and pice-goods. Methods of chemical tests.

8. Methodical instructions of the IUK 4.1/4.3.1485-03. Hygienic clothes for children, adolescents and adults.

9. GOST R Textiles. Maximum permissible concentrations of free formaldehyde (adopted as an interstate standard GOST 30386-95).

10. GOST R 52557-2011. Paper children's diapers. General specifications.

11. GOST R 55082-2012. Articles of paper for medical purposes. Diapers for adults. General specifications.

12. GOST R 5080-2018. Composition cellulose material for absorbing sanitary-hygiene paper products. Specifications.

13. Uoker Dzh. F. Formaldehyde: Per. s angl. M.: Goskhimizdat, 1957, 608 p.

14. Commodity certificates and certificates of conformity for hygiene products for children diapers (diapers) based on cellulose
$97-102$

manufactured in Finland by the companies "Papyriset" and "Delipap".

15. Khakhenberg Kh., Shmid A. Gazokhromatograficheskij analiz ravnovesnoj parovoj fazy: Per. s angl. M.: Mir, 1979. 160 p.

16. Vittenberg A.G., Ioffe B.V. Gazovaya ehkstraktsiya $\mathrm{v}$ khromatograficheskom analize. Parofaznyj analiz i rodstvennye metody. L.: Khimiya, 1982, 279 p.

17. Ioffe B.V., Reznik T.L., Zhurn. analit. Khimii, 1980, Vol. 35, No 7, pp. 1410-1427.

18. Burejko A.S., Ioffe B.V., Zhurn. analit. Khimii, 1991, Vol. 46, No 3, pp. 452-460.

19. Khabarov V.B., Analitika i kontrol', 2013, Vol. 17, No 2, pp. 196-203.

20. Khabarov V.B., Sorbtsionnye i khromatograficheskie protsessy, 2015, Vol. 15, No 2, pp. 196-215.

21. Khabarov V.B., Sorbtsionnye i khromatograficheskie protsessy, 2013, Vol. 13, No 6, pp. 947-958.

22. Khabarov V.B., Mal'tsev V.V. C.C. USSR No 1728793, 1992.

23. Khabarov V.B., Panina L.I., Sakodynskij K.I., Kovba I.T., Glazunova L.D. C.C. USSR No 1258179, 1986.

24. Glazunova L.D., Panina L.I., Sakodynskij K.I., Zabel'nikov N.S. C.C. USSR No 699422, 1979.

25. Glazunova L.D., Panina L.I., Sakodynskij K.I., Tezisy dokladov «Primenenie khromatografii v khimii i khimicheskoj promyshlennosti». 10-12 iyunya 1981 g. G. Perm' 1981, pp. 4.

26. Khabarov V.B., Panina L.I., Chumicheva O.A., Sorbtsionnye $i$ khromatograficheskie protsessy, 2014 Vol. 14, No 2, pp. 240-253.

27. Khabarov V.B., Mal'tsev V.V. C.C. USSR No 1350610, 1987.

28. Khabarov V.B., Sorbtsionnye i khromatograficheskie protsessy, 2012, Vol. 12, No 4, pp. 513-522.

29. Tekhnicheskie usloviya 301-05-89-90. Ampuly ftoroplastovye. Kirovo-Chepetskij khimicheskij kombinat, 1990, 9 p.

30. Raymond A., Guiochon G., J. Chromatog. Sci., 1975, Vol . 13, pp. 173-177.

31. Gavrilina L.YA., Zhejvot V.I., Emel'yanov I.D., Izv. SO AN USSR, 1982, No 7, pp. 97-102. 
Хабаров Виктор Борисович - к.Х.н., старший научный сотрудник, ФГБУН Институт физической химии и электрохимии им. А.Н. Фрумкина РАН (ИФХЭ РАН), Москва, тел.: 8(495)9554668

Панина Лариса Ивановна - д.х.н., професcop, главный научный сотрудник НИОКО «Биоэкомониторинг», Москва

Львов Анатолий Иванович - инженер конструктор НИОКО «Биоэкомониторинг», Москва
Khabarov Victor B. - Candidat of Chemistry, senior research worker, Federal State Budgetary Foundation of Science A.N. Frumkin, Institute of Physical Chemistry and Electrochemistry of the Russian Academy of Sciences, Moscow, e-mail: Khabarov@phyche.ac.ru

Panina Larisa I. - Doctor of Chemical sciens, professor, the main scientific worker NIOKO «Bioecomonitoring», Moscow

L'vov Anatolij I. - design engineer NIOKO «Bioecomonitoring», Moscow 